\title{
Dari Sikap Radikal Menuju Perilaku Terorisme : Deskripsi Perilaku Teroris di Kabupaten Lamongan
}

\author{
Nur Ika Fatmawati \\ Pendidikan Agama Islam, Universitas Islam Negeri Sunan Kalijaga \\ fatmanaura.ahmad@gmail.com \\ Ahmad Farid \\ Pegawai Kecamatan Turi, Kabupaten Lamongan \\ farid.ahmad@gmail.com
}

Received: 01 Juli 2020; Revised: 10 Juli 2020; Accepted : 20 Juli 2020; Published : Agustus 2020; Available online : Agustus 2020.

\begin{abstract}
The Indonesian state has lived and grown based on the diversity of ethnic groups, religions, beliefs and customs that have developed beyond the age of this republic. Because of these factors, the founders of this nation formulated the values and philosophies of the nation which were abstracted in the Pancasila and also the opening of the Constitution as the basis of the country's constitution. One of the values is tolerance and respect for the different. These values are manifested in daily life or also manifested in policies that protect all citizens without exception. Unfortunately, over time and global developments that continue to change, these values and principles eroded so that they become a source of social conflict. One of the problems that continues to emerge in the Indonesian public sphere is religious intolerance, radicalization and terrorism. Religious intolerance, radicalization and terrorism are manifested in the prohibition of religious worship activities, the spread of hatred, religious based violence or the destruction of places of worship. In addition to increasingly diverse forms of intolerance, the territory is also expanding. Initial studies show that there is a strong geographical link between the growth of religious intolerance and the recruitment of terrorist groups and ISIS. Religious intolerance has occurred in almost all regions of Indonesia, as well as the radicalization of religion and terrorism.
\end{abstract}

Keywords: Radicalism, Terrorism, Lamongan 


\section{Pendahuluan}

Indonesia dikenal sebagai Negara bangsa yang hidup dan tumbuh berbasis keragaman suku bangsa, agama, kepercayaan serta adat istiadat yang berkembang melebihi umur republik ini. Karena faktor-faktor tersebutlah para pendiri bangsa ini merumuskan nilainilai dan falsafah bangsa yang disarikan dalam Pancasila dan juga pembukaan UUD sebagai basis konstitusi Negara. Salah satu nilai yang ada adalah toleransi dan penghormatan kepada yang berbeda. Nilai-nilai tersebut termanifestasikan dalam kehidupan sehari-hari atau juga diwujudkan dalam kebijakan yang melindungi semua warga Negara tanpa terkecuali. Sayangnya, seiring perjalanan waktu dan perkembangan global yang terus berubah, nilai dan prinsip tersebut terkikis sehingga menjadi sumber konflik sosial.

Salah satu permasalahan yang saat ini terus mengemuka ke dalam ranah publik Indonesia adalah Intoleransi, radikalisasi dan terorisme agama. Intoleransi, radikalisasi dan terorisme agama diwujudkan dalam pelarangan kegiatan ibadah keagamaan, penyebaran kebencian, kekerasan berbasis agama ataupun pengrusakan tempat ibadah. Selain bentuk-bentuk intoleransi yang semakin beragam, wilayahnya juga semakin meluas. Berbagai penelitian awal menunjukkan bahwa ada kaitan geografis yang kuat antara tumbuhnya intoleransi keagamaan dengan perekrutan kelompok teroris dan ISIS. Intoleransi keagamaan sudah terjadi hampir di seluruh wilayah Indonesia, demikian juga dengan radikalisasi agama dan terorisme.

Indonesia dalam rentang waktu 10 tahun ini mengindikasikan adanya gejala intoleransi, radikalisme dan terorisme. Terorisme, penyerangan dan pengusiran terhadap kelompok minoritas, pelarangan kegiatan, dan pembakaran buku adalah sebagian bentuk intoleransi dan radikalisme itu. Indonesia masih menyimpan potensi intoleransi dan radikalisme, sebagian dari itu sudah terjadi meski hanya di beberapa daerah, sebagian besarnya bukan tidak mungkin akan muncul ke permukaan secara masif di waktu yang akan datang, jika tidak ditangani secara sungguh-sungguh.

Dibeberapa kampus perguruan tinggi umum, kecenderungan mahasiswa untuk mendukung tindakan radikalisme juga sangat tinggi. Hal ini terungkap dalam penelitian tentang Islam Kampus yang melibatkan 2466 sampel mahasiswa dari berbagai perguruan 
tinggi ternama di Indonesia. Ketika para mahasiswa ditanya tentang pelaksanaan amar makruf nahi munkar dalam bentuk sweeping tempat-tempat yang dianggap sumber maksiyat, mereka menjawab sebagai berikut: sekitar 65\% (1594 responden) mendukung dilaksanakannya sweeping kemaksiyatan, 18\% (446 responden) mendukung sekaligus berpartisipasi aktif dalam kegiatan sweeping. Selanjutnya, mereka yang mendukung sweeping beralasan bahwa kegiatan sweeping tersebut sebagai bagian dari perintah agama (88\%), mendukung sweeping karena berpendapat bahwa aparat keamanan tidak mampu menegakkan hukum (4\%), dan karena alasan dekadensi moral (8\%) (Fadjar, 2007 : 35).

Fenomena kekerasan atas nama agama yang sering dikenal dengan radikalisme agama semakin tampak garang ketika muncul berbagai peristiwa teror pemboman di tanah air. Beberapa peristiwa teror dalam bentuk pengeboman telah memakan banyak korban dan berdampak luas terhadap kehidupan sosial masyarakat Indonesia. Setidaknya telah terjadi lebih dari 20 kali peristiwa pemboman sejak tahun 2000 sampai sekarang (Wikipedia, 2017). Jaringan terorisme terus bekerja dan perekrutan orang baru untuk menjalankan aksi teror masih berlangsung, meski tokoh-tokoh utama pelaku teror sudah ditahan. Hal ini sejalan dengan temuan Wahid Foundation dalam laporannya tahun 2014, ditemukan bahwa dari 230 organisasi yang telah berdiri sejak zaman Orde Lama, 147 diidentifikasi sebagai organisasi intoleran, 49 organisasi memiliki kecenderungan pada radikalisme, dan 34 organisasi terindikasi sebagai kelompok terror.

Penelitian ini mengambil lokasi di Lamongan karena kota ini menyumbang banyak sekali tokoh-tokoh terorisme yang ada di Indonesia. Mengutip laporan IPAC (Institute for Policy Analysis of Conflict) soal Jaringan Lamongan, kota ini dikenal sebagai wilayah dengan sekolahsekolah agama penelur tokoh teror. Analisis yang dilakukan terhadap hubungan tokoh-tokoh di Lamongan menunjukkan jaringan alumni pesantren Al Islam dan sekolah lainnya pernah berhubungan dengan organisasi Jamaah Islamiyah. Walaupun tokoh-tokoh ini bukan atau dalam beberapa kasus, bukan lagi anggota JI, sekolah-sekolah ini tetap menjadi komponen penting untuk komunitas ekstremis setelah JI sendiri sudah berhenti, setidaknya sementara, melakukan kekerasan. 
Dari uraian di atas dapat di tarik permasalahan sebagai berikut: Bagaimana perilaku radikalisme bisa mengarah pada tindakan terorisme di Kabupaten Lamongan. Bagaimana mencegah atau mengurangi perilaku radikalisme supaya tidak mengarah kepada terorisme di Kabupaten Lamongan.

\section{PEMBAHASAN}

\section{Pengertian Toleransi Agama}

Istilah radikalisme berasal dari bahasa Latin "radix" yang artinya akar, pangkal, bagian bawah, atau bisa juga berarti menyeluruh, habis-habisan dan amat keras untuk menuntut perubahan. Menurut Kamus Besar Bahasa Indonesia (KBBI) radikalisme berarti (1) paham atau aliran yang radikal dalam politik; (2) paham atau aliran yang menginginkan perubahan atau pembaharuan sosial dan politik dengan cara kekerasan atau drastis; (3) sikap ekstrem dalam aliran politik. ${ }^{1}$ Setidaknya, radikalisme bisa dibedakan ke dalam dua level, yaitu level pemikiran dan level aksi atau tindakan. Pada level pemikiran, radikalisme masih berupa wacana, konsep dan gagasan yang masih diperbincangkan, yang intinya mendukung penggunaan cara-cara

\footnotetext{
${ }^{1}$ Departemen Pendidikan dan Kebudayaan, (1995). Kamus Besar Bahasa Indonesia, Ed.II; Jakarta: Balai Pustaka,hlm. 115
}

kekerasan untuk mencapai tujuan. Adapun pada level aksi atau tindakan, radikalisme bisa berada pada ranah sosial-politik dan agama. Pada ranah politik, faham ini tampak tercermin dari adanya tindakan memaksakan pendapatnya dengan cara-cara yang inkonstitusional, bahkan bisa berupa tindakan mobilisasi masa untuk kepentingan politik tertentu dan berujung pada konflik sosial.

Dalam bidang keagamaan, fenomena radikalisme agama tercermin dari tindakan-tindakan destruktifanarkis atas nama agama dari sekelompok orang terhadap kelompok pemeluk agama lain (eksternal) atau kelompok seagama (internal) yang berbeda dan dianggap sesat. Lebih detil, Rubaidi menguraikan lima ciri gerakan radikalisme. Pertama, menjadikan Islam sebagai ideologi final dalam mengatur kehidupan individual dan juga politik ketata negaraan. Kedua, nilai-nilai Islam yang dianut mengadopsi sumbernya di Timur Tengah secara apa adanya tanpa mempertimbangkan perkembangan sosial dan politik ketika Al-Quran dan hadits hadir di muka bumi ini, dengan realitas lokal kekinian. Ketiga, karena perhatian lebih terfokus pada teks AlQur'an dan hadist, maka purifikasi ini sangat berhati-hati untuk menerima 
segala budaya non asal Islam (budaya Timur Tengah) termasuk berhati-hati menerima tradisi lokal karena khawatir mencampuri Islam dengan bid'ah. Keempat, menolak ideologi Non-Timur Tengah termasuk ideologi Barat, seperti demokrasi, sekularisme dan liberalisme. Kelima, gerakan kelompok ini sering berseberangan dengan masyarakat luas termasuk pemerintah. Oleh karena itu, terkadang terjadi gesekan ideologis bahkan fisik dengan kelompok lain, termasuk pemerintah. ${ }^{2}$

Menurut Simon Tormey dalam International Enyclopedia of Social Sciences (Vol.7, hal 48), radikalisme merupakan sebuah konsep yang bersifat kontekstual dan posisional, dalam hal ini kehadirannya merupakan antitesis dari ortodoks atau arus utama (mainstream), baik bersifat sosial, sekuler, saintifik, maupun keagamaan. Menurutnya, radikalisme tidak mengandung seperangkat gagasan dan argumen, melainkan lebih memuat posisi dan ideologi yang mempersoalkan atau menggugat sesuatu (atau segala sesuatu) yang dianggap mapan, diterima, atau menjadi pandangan umum. ${ }^{3}$ Radikalisme

${ }^{2}$ A. Rubaidi, Radikalisme Islam, Nahdlatul Ulama; Masa Depan Moderatisme Islam di Indonesia, (Yogykarta: Logung Pustaka, 2010), hlm. 63

3 Azca, Muhammad Najib. Yang Muda, Yang Radikal: Refleksi Sosiologis Terhadap Fenomena Radikalisme Kaum Muda Muslim di Indonesia adalah paham atau aliran yang menginginkan perubahan atau pembaharuan sosial dan politik dengan cara kekerasan atau drastis. Sedangkan Kelompok Islam radikal adalah sebuah gerakan politik ekstrim yang berusaha membentuk negara Islam melalui perjuangan bersenjata. Dimana terdapat doktrin-doktrin pada kelompok untuk membenarkan tindakan kekerasan untuk menghilangkan rezim di dunia yang dianggap kafir saat ini. Dan karena tindakan kekerasan inilah, maka gerakan Islam radikal seringkali di cap sebagai teroris oleh negara-negara barat khususnya Amerika. ${ }^{4}$

$$
\text { Radikalisasi adalah proses }
$$
perubahan di mana kelompok mengalami transformasi ideologi atau perilaku yang mengarah pada penolakan prinsipprinsip demokrasi dengan cara menuntut untuk dilakukannya revolusi di bidang sosial politik, sosial ekonomi, dan perubahan budaya dengan jalan kekerasan atau peningkatan tingkat kekerasan, untuk mencapai tujuan politik. Pada dasarnya radikalisasi muncul akibat adanya kesenjangan dan

Pasca Orde Baru. Jurnal Maarif, Vol. 8, No. 1 (Juli 2013): 14-41.

4 Cavatorta, Francesco, (2005). The War on Terrorism"-Perspectives from Radical Islamic Groups. Journal of Irish Studies in International Affairs, Vol. $16 \quad$ (2005). Diakses dari http://doras.dcu.ie/488/1/isia_16_April_2017.pdf 
marjinalisasi politik. Adapun tujuan dari kelompok-kelompok radikal di indonesia adalah menciptakan negara islam. Dalam mencapai tujuan, kelompok ini melakukan proses rekruitmen anggota mulai dari tingkat sekolah hingga universitas. Dan biasanya proses indoktrinasi ini dilakukan melalui kegiatan ekstrakurikuler agama yang ada di sekolah maupun perguruan tinggi. Ada 3 cara yang dapat ditempuh untuk menganalisis munculnya gerakan islam radikal di indonesia yakni: 1. Konteks historis; munculnya islam radikal di indonesia. 2. Konteks global; kebangkitan gerakan jihad, 3. Implementasi syariah sebagai ideologi negara. ${ }^{5}$

Radikalisme memiliki istilah yang beragam, ada yang menyebut radikalisme dengan istilah fundamentalisme, ada pula yang menyebutnya sebagai ekstrimisme bahkan ada pula yang mengaitkannya dengan terorisme. Penamaan ini disebabkan karena makna yang terkandung dalam istilah-istilah tersebut hampir sama. Jika radikalisme disebut sebagai paham yang cenderung menggunakan jalan kekerasan, maka istilah fundamentalisme dimaknai

${ }^{5}$ Hasan, Noorhaidi. Islam di Ruang Publik; Politik Identitas dan Masa Depan Demokrasi di Indonesia. Jakarta; Center for Study of Religion and CultureKAS, 2010. sebagai paham yang cenderung untuk memperjuangkan sesuatu secara radikal, selanjutnya ekstrimisme dimaknai sebagai paham yang cenderung ekstrim (keras). Selanjutnya istilah terorisme sering pula dikaitkan dengan radikalisme karena terorisme mengandung makna penggunaan kekerasan untuk menimbulkan rasa takut dalam usaha mencapai suatu tujuan. ${ }^{6}$

\section{Terorisme}

Terorisme bukan persoalan siapa pelaku, kelompok dan jaringannya. Namun, lebih dari itu terorisme merupakan tindakan yang memiliki akar keyakinan, doktrin dan ideologi yang dapat menyerang kesadaran masyarakat. Tumbuh suburnya terorisme tergantung di lahan mana ia tumbuh dan berkembang. Jika ia hidup di tanah gersang, maka terorisme sulit menemukan tempat, sebaliknya jika ia hidup di lahan yang subur maka ia akan cepat berkembang. Ladang subur tersebut menurut Hendropriyono adalah masyakarat yang dicemari oleh paham fundamentalisme ekstrim atau

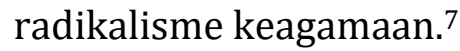

\footnotetext{
${ }^{6}$ Departemen Pendidikan dan Kebudayaan, (1995). Kamus Besar Bahasa Indonesia, Ed.II; Jakarta: Balai Pustaka, Hlm. 281, 255, 1048

${ }^{7}$ A.M. Hendroprioyono, Terorisme: Fundamentalis Kristen, Yahudi dan Islam (Jakarta: Buku Kompas, 2009), hlm. 13.
} 
Radikalisme merupakan suatu sikap yang mendambakan perubahan secara total dan bersifat revolusioner dengan menjungkirbalikkan nilai-nilai yang ada secara drastis lewat kekeraan (violence) dan aksi-aksi yang ekstrem. Ada beberapa ciri yang bisa dikenali dari sikap dan paham radikal. 1. Intoleran (tidak mau menghargai pendapat \& keyakinan orang lain), 2. Fanatik (selalu merasa benar sendiri; menganggap orang lain salah), 3. Eksklusif (membedakan diri dari umat Islam umumnya) dan 4. Revolusioner (cenderung menggunakan cara-cara kekerasan untuk mencapai tujuan).

Memiliki sikap dan pemahaman radikal saja tidak mesti menjadikan seseorang terjerumus dalam paham dan aksi terorisme. Ada faktor lain yang memotivasi seseorang bergabung dalam jaringan terorisme. Motivasi tersebut disebabkan oleh beberapa faktor. Pertama, Faktor domestik, yakni kondisi dalam negeri yang semisal kemiskinan, ketidakadilan atau merasa Kecewa dengan pemerintah. Kedua, faktor internasional, yakni pengaruh lingkungan luar negeri yang memberikan daya dorong tumbuhnya sentiment keagamaan seperti ketidakadilan global, politik luar negeri yg arogan, dan imperialisme modern negara adidaya.
Ketiga, faktor kultural yang sangat terkait dengan pemahaman keagamaan yang dangkal dan penafsiran kitab suci yang sempit dan leksikal (harfiyah). Sikap dan pemahaman yang radikal dan dimotivasi oleh berbagai faktor di atas seringkali menjadikan seseorang memilih untuk bergabung dalam aksi dan jaringan terorisme.

Lalu apa itu terorisme ? Banyak ragam pengertian dalam mendefinisikan terorisme. Dari beragam definisi baik oleh para pakar dan ilmuwan maupun yang dijadikan dasar oleh suatu negara, setidaknya memuat tiga hal: pertama, metode, yakni menggunakan kekerasan; kedua, target, yakni korban warga sipil secara acak, dan ketiga tujuan, yakni untuk menebar rasa takut dan untuk kepentingan perubahan sosial politik. ${ }^{8}$ Karena itulah, definisi yang dijadikan dasar oleh negara Indonesia dalam melihat terorisme pun tidak dilepaskan dari tiga komponen tersebut Dalam UU No.15 Tahun 2003 tentang Pemberantasan Tindak Pidana Terorisme disebutkan : Setiap orang yang dengan sengaja menggunakan kekerasan atau ancaman kekerasan menimbulkan situasi teror atau rasa takut terhadap orang secara meluas atau

\footnotetext{
${ }^{8}$ Harvey W. Kushner, Encyclopedia of Terrorism, London : Sage Publication, 2003. Hlm. Xxiii.
} 
menimbulkan korban yang bersifat massal, dengan cara merampas harta benda orang lain, atau mengakibatkan kerusakan atau kehancuran terhadap obyek-oyek vital strategis atau lingkungan hidup atau fasilitas publik atau fasilitas internasional. ${ }^{9}$

Dari Intoleran dan Radikalisme hingga menjadi Terorisme

Nilai Budaya dan Praktik Sosial

Di lapisan dasar, nilai budaya dan praktik sosial berperan dalam menghasilkan kecenderungan toleran/intoleran dan radikal. Praktik toleransi/intoleransi dan radikalisme terkait dengan nilai dan praktik sosial yang ada di masyarakat. Apa yang diyakini oleh individu-individu di masyarakat dapat dipahami sebagai representasi sosial, sebagai ide dan keyakinan yang ada di masyarakat, yang diinternalisasi oleh individu. Representasi sosial adalah sekumpulan nilai, ide, metafora, keyakinan, dan praktik yang dibagi bersama di antara anggota kelompok dan komunitas (Moscovici, 1973).

Representasi sosial itu memungkinkan orang-orang dalam satu kelompok atau komunitas berbicara satu sama lain dan bertindak bersama serta

9 Lihat UU No.15 Tahun 2003 tentang Pemberantasan Tindak Pidana Terorisme saling berinteraksi. Itu menjadi seperangkat pengertian bersama dan memandu praktik sosial. Sistem nilai, ide dan praktik itu memiliki dua fungsi. Pertama, menegakkan keteraturan yang akan memampukan individu mengorientasikan dirinya dalam dunia material dan sosial, serta memampukannya melakukan penyesuaian diri dan penanganan lingkungan. Kedua, memungkinkan komunikasi mengenai beragam aspek dunia, individu dan kelompok berlangsung di antara anggota komunitas dengan menyediakan bagi peserta komunikasi kode untuk pertukaran sosial, penamaan dan klasifikasi secara jelas. Makna dikreasi melalui sistem negosiasi sosial ketimbang hal yang sudah ajek dan terdefinisikan. Penafsirannya mensyaratkan pengertian atas aspek tambahan dari lingkungan sosial.

Kondisi Perekonomian

Di lapisan berikutnya, kondisi perekonomian berperan dalam menghasilkan kecenderungan toleran/intoleran dan radikal. Kondisi perekonomian yang meleluasakan warga mengambil peranan dan memperoleh sumber daya memadai atau relatif merata, disertai ketimpangan ekonomi relatif rendah, mencegah timbulnya 
kecenderungan intoleransi dan

radikalisme.

\section{Keragaman Sumber Norma}

Di lapisan berikutnya ditemukan faktor keragaman sumber norma ikut berperan dalam kecenderungan tolerasnsi/intoleransi dan radikalisme. Masyarakat yang hanya berpegang pada satu atau sedikit sumber norma menampilkan kecenderungan intoleran yang lebih tinggi, dari pada masyarakat yang mengandalkan banyak sumber norma. Namun perlu ditegaskan pula, beragam sumber norma itu harus memiliki hubungan positif atau kesesuaian antara satu dan lainnya, jika tidak maka bisa terjadi kebingungan pada warganya, untuk mengikuti norma yang mana dalam kehidupannya seharihari.

\section{Pengaruh Tokoh Signifikan}

Di lapisan berikutnya, faktor pengaruh tokoh yang signifikan dan dianggap penting oleh warga turut berperan terhadap kecenderungan toleran/intoleran dan radikalisme.

Kehadiran dan Keberfungsian Negara

Di lapisan paling atas, kehadiran dan keberfungsian negara berperan sebagai faktor penting dalam kecenderungan toleran/intoleran dan radikalisme. Di Kabupaten Lamongan yang diteliti ditemukan peran kehadiran dan keberfungsian negara dalam gejala toleran/intoleansi dan radikalisme. Peran negara yang diwakili pemerintah daerah dapat meningkatkan atau menurunkan gejala intoleransi dan radikalisme. Jika negara hadir dan menjalankan fungsi-fungsi yang efektif dan menjaga toleransi, maka kcederungan toleran pada warga akan lebih besar. Peran negara yang dimaksud di sini adalah berikap netral dan tegas, bekerja sesuai payung hokum yang tidak diskriminatif, antisipatif dengan menyiapkan semacam sistem peringatan dini (Early Warning System) kepada warga, untuk menghindar dari kecenderungan intoleran dan radikal, serta mampu memediasi dan koordinasi. Gejala toleransi/intoleransi dan radikalisme disebabkan oleh lebih dari satu faktor yang secara bersama-sama bekerja. Dalam pencermatan terhadap empat kota yang diteliti, semua faktor itu bekerja bersama-sama dalam porsi tertentu dalam menghasilkan kecenderungan tolerans/intoleransi dan radikalisme. Skema berikut ini meringkas faktor-faktor yang sudah dipaparkan di atas.

Intoleran didefinisikan sebagai ketidaksediaan atau ketidakmauan untuk memberikan hak pada orang atau kelompok yang berbeda, baik berbeda 
dalam keyakinan, ideologi, status sosial, maupun etnik. Sedangkan radikalisme adalah keyakinan seseorang yang begitu tinggi terhadap satu faham atau nilai, yang membuat ia menutup kemungkinan benar faham-faham lain, disertai dengan pandangan bahwa yang lain salah, sehingga layak diabaikan, dihilangkan atau dihukum. Radikalisme juga dipahami sebagai intoleransi dalam bentuk ekstrem, disertai dengan kecenderungan untuk menggunakan kekerasan, yang ditujukan kepada orang atau kelompok yang berbeda faham. Berdasarkan pengertian-pengertian ini, dan hasil studi di Kabupaten Lamongan yang diteliti, dibangun satu model penjelasan mengenai toleransi/intoleransi, radikalisme hingga terorisme.

Model ini menjelaskan hubungan antara perbedaan keyakinan dan toleransi/ intoleransi yang dimediasi oleh kepentingan ekonomi. Perbedaan keyakinan mempengaruhi toleransi/intoleransi bermuatan kepentingan ekonomi (termasuk juga kepentingan politik yang bertujuan memperoleh sumber daya ekonomi). Perbedaan keyakinan atau etnik saja tidak signifikan pengaruhnya terhadap toleransi/ intoleransi. Dalam berbagai kasus intoleransi selalu ada peran faktor ekonomi di dalamnya, yang menghubungkan perbedaan keyakinan atau etnik dengan intoleransi. Hubungan ini dimoderasi oleh kehadiran negara. Tingkat kehadiran negara yang tinggi memperkuat hubungan antara perbedaan dan toleransi, serta memperkuat hubungan antara perbedaan dan kepentingan ekonomi.

Nilai budaya dan praktik sosial berperan sebagai moderator dalam hubungan antara kepenting ekonomi dan toleransi/intoleransi, serta hubungan antara perbedaan dan toleransi/intoleransi. Seberapa kuat perbedaan menghasilkan kecenderungan toleransi/intoleransi ikut dipengaruhi oleh nilai budaya dan praktik sosial. Begitu juga seberapa kuat ketimpangan ekonomi mempengaruhi toleransi/intoleransi dipengaruhi oleh oleh nilai budaya dan praktik sosial. Radikalisme merupakan hasil pengaruh dari intoleransi. Semakin intoleran seseorang, semakin besar kemungkinannya untuk menjadi radikal. Tidak semua orang yang intoleran adalah orang yang radikal, tetapi semua orang yang radikal, dalam pengertian menggunakan kekerasan untuk menghadapi orang atau kelompok yang berbeda, adalah orang yang intoleran. 
Gejala toleransi/intoleransi dan radikalisme memiliki lebih dari satu sebab (multicausal). Seperti gejala sosial pada umumnya, tidak ada penyebab tunggal dari toleransi/intoleransi. Selain itu, bukan hanya keberadaan faktor tertentu saja yang memunculkan gejala toleransi/intoleransi, melainkan juga bagaimana hubungan antar faktor. Keberadaan semua faktor tersebut saja belum tentu memunculkan intoleransi atau radikalisme. Tanpa adanya hubungan yang signifikan antara faktor, gejala toleransi/intoleransi tidak muncul. Guna dapat memahami gejala toleransi/intoleransi dan radikalisme dibutuhkan analisis komprehensif, terhadap faktor-faktornya serta pencermatan terhadap hubungan antara faktor-faktor itu.

Meskipun ada banyak faktor yang berperan dalam munculnya gejala toleransi/ intoleransi dan radikalisme, berdasarkan model yang dihasilkan studi ini, ada faktor yang dapat dikenali sebagai faktor yang mendahului yang lain. Ada perbedaan keyakinan, etnik, status sosial ekonomi, dan sebagainya menjadi gejala awal yang berpotensi menghasilkan gejala toleransi/intoleransi dan radikalisme. Namun, seperti yang diketahui bersama, perbedaan itu seringkali merupakan situasi yang terberi dan tak terhindarkan. Juga perlu dipahami bahwa perbedaan itu tidak serta merta menghasilkan intoleransi apalagi radikalisme. Ada kepentingan ekonomi yang berperan menghubungkan perbedaan dengan intoleransi, yang jika semakin menguat nantinya dapat menghasilkan pula radikalisme.

Di sisi lain ada peran kehadiran negara, yang dapat mengurangi atau menguatkan peran kepentingan ekonomi dalam menghasilkan intoleransi. Kehadiran negara juga berperan dalam memperkuat hubungan antara perbedaan dan intoleransi. Faktor kehadiran Negara menjadi penting dalam konteks ini dan lebih dapat dikendalikan dari pada faktor perbedaan. Hadirnya negara menjadi faktor yang dapat diupayakan. Jika negara dapat menjalankan fungsinya dalam arti bersikap netral dan tegas, bekerja sesuai payung hukum yang tidak diskriminatif, antisipatif dengan menyiapkan semacam sistem peringatan dini kepada warga, maka kecenderungan intoleran dan radikal dapat dihindari dan dihilangkan. Negara yang mampu memediasi dan mengkoordinasi para pihak di masyarakat menjadi kunci penting bagi 
munculnya toleransi. Peran negara juga penting untuk menjaga agar kepentingan ekonomi tidak membuat perbedaan menjadi faktor yang meningkatkan kecenderungan intoleransi dan radikalisme.

Jika nilai budaya dan praktik sosial yang sejalan dengan toleransi kuat, maka intoleransi dan radikalisme juga dapat dihambat. Sebaliknya, jika nilai budaya dan praktik sosial memfasilitas menguatnya persepsi akan perbedaan dan petentangan kepentingan ekonomi, maka intoleransi dan radikalisme cenderung menguat. Tetapi, peran nilai budaya dan praktik sosial akan lebih kecil, jika sedari awal kehadiran negara berperan optimal dan berfungsi untuk menghindarkan warga dari sikap menjadikan perbedaan dan kepentingan ekonomi, sebagai penyebab intoleransi dan radikalisme. Merujuk pada model ini, dalam upaya mendorong masyarakat Indonesia menjadi masyarakat yang toleran, kehadiran negara perlu diupayakan untuk mencegah terjadinya intoleransi dan radikalisme. Sebaliknya, jika negara justru mendukung atau membiarkan kecenderungan dan praktik intoleransi berjalan, maka kemungkinan terjadinya tindakan intoleran sangat besar. Begitu pula dengan gejala radikalisme, kehadiran negara menjadi faktor yang besar pengaruhnya.

\section{KESIMPULAN}

Hasil kajian di Kabupaten Lamongan ini memberikan pemahaman mengenai faktor apa saja yang secara signifikan mempengaruhi perspektif dan perilaku warga terkait perilaku intoleransi, radikalisme dan terorisme. Faktor yang berperan itu mencakup demografi, latar belakang budaya dan politik, affiliasi dan asosiasi, kebijakan, Nilai, Ideologi, makna agama, akses terhadap media sosial. Hubungan antara faktor-faktor toleransi/intoleransi dan radikalisme dapat dilihat berdasarkan letak faktor-faktor itu dalam lapisan sosial, mulai dari nilai yang tercakup dalam budaya hingga faktor struktural, yang mencakup kebijakan dan keberfungsian negara.

Di lapisan dasar, nilai budaya dan praktik sosial berperan dalam menghasilkan kecenderungan toleran/intoleran dan radikal. Di lapisan berikutnya, kondisi perekonomian berperan dalam menghasilkan kecenderungan toleran/intoleran dan radikal. Lalu, faktor keragaman sumber norma ikut berperan dalam kecenderungan toleransi/intoleransi dan radikalisme ada di lapisan berikutnya. Di 
lapisan berikutnya lagi, faktor pengaruh tokoh yang signifikan dan dianggap penting oleh warga turut berperan terhadap kecenderungan tolern/intoleran dan radikalisme. Di lapisan paling atas, kehadiran dan keberfungsian Negara berperan sebagai faktor penting dalam kecenderungan toleran/intoleran dan radikalisme.

Perbedaan

keyakinan

mempengaruhi toleransi/intoleransi bermuatan kepentingan ekonomi (termasuk juga kepentingan politik, yang bertujuan memperoleh sumber daya ekonomi). Perbedaan keyakinan atau etnik saja tidak signifikan pengaruhnya terhadap toleransi/intoleransi. Nilai budaya dan praktik sosial berperan sebagai moderator dalam hubungan antara kepenting ekonomi dan toleransi/intoleransi, serta hubungan antara perbedaan dan toleransi/intoleransi. Radikalisme merupakan hasil pengaruh dari intoleransi. Semakin intoleran seseorang, semakin besar kemungkinannya untuk menjadi radikal. Gejala toleransi/intoleransi dan radikalisme memiliki lebih dari satu sebab (multicausal). Seperti gejala sosial pada umumnya, tidak ada penyebab tunggal dari toleransi/intoleransi. Meskipun demikian, berdasarkan model yang dihasilkan studi ini, ada faktor yang dapat dikenali sebagai faktor yang mendahului yang lain.

Kepentingan ekonomi yang berperan menghubungkan perbedaan dengan intoleransi, yang jika makin menguat nanti dapat menghasilkan pula radikalisme. Di sisi lain ada peran kehadiran negara, yang dapat mengurangi atau menguatkan peran kepentingan ekonomi dalam menghasilkan intoleransi. Kehadiran Negara juga berperan dalam memperkuat hubungan antara perbedaan dan intoleransi. Jika nilai budaya dan praktik sosial yang sejalan dengan toleransi kuat, maka intoleransi dan radikalisme juga dapat dihambat, dan sebaliknya. Tetapi, peran nilai budaya dan praktik sosial akan lebih kecil jika sedari awal kehadiran Negara berperan optimal dan berfungsi untuk menghindarkan warga, untuk menjadikan perbedaan dan kepentingan ekonomi sebagai penyebab intoleransi dan radikalisme. Untuk dapat mendorong masyarakat Indonesia agar menjadi masyarakat yang toleran, kehadiran negara perlu diupayakan untuk mencegah terjadinya intoleransi dan radikalisme. Sebaliknya, jika negara justru mendukung atau membiarkan kecenderungan dan praktik intoleransi 
berjalan, maka kemungkinan terjadinya tindakan intoleran sangat besar. Itu berlaku juga pada gejala radikalisme.

\section{Daftar Pustaka}

Azca, Muhammad Najib. 2013. Yang Muda, Yang Radikal: Refleksi Sosiologis Terhadap Fenomena Radikalisme Kaum Muda Muslim di Indonesia Pasca Orde Baru\| Jurnal Maarif, Vol. 8, No. 1 (Juli 2013): 14-41.

Cavatorta, Francesco. 2005. The =War on Terrorism'-Perspectives from Radical Islamic Groups. Journal of Irish Studies in International Affairs, Vol. 16 (2005). Diakses dari

http://doras.dcu.ie/488/1/isia 1

6 April 2017.pdf

Departemen Pendidikan dan

Kebudayaan, 1995. Kamus Besar Bahasa Indonesia, Ed.II; Jakarta: Balai Pustaka.

Fadjar, Abdullah dkk, 2007. Laporan Penelitian Islam Kampus. Jakarta:Ditjen Dikti Depdiknas.

Kushner, Harvey W. 2003. Encyclopedia of Terrorism, London : Sage Publication.

Marsh, David dan Gerry Stoker. 2002. Theory and Methods in Politial Science. Hampshire: Palgrave Macmilla.
Moleong, Lexy J. 2004 . Metodologi Penelitian Kualitatif. Bandung: PT Remaja Rosdakarya.

Peninjauan kembali Pendidikan Agama Islam. Dalam www.swattonline.com/2017/04/lakippemerintah-harus-tinjaukembalipendidikan-agama-islam / di akses 10/04/2017 20:30 WIB

Rubaidi, A. 2010. Radikalisme Islam, Nahdlatul Ulama; Masa Depan Moderatisme Islam di Indonesia. Yogykarta: Logung Pustaka.

Terorisme di Indonesia, 2017. http://id.wikipedia.org/wiki/Ter orisme di Indonesia, diakses 20/04/2017, 20:39 WIB

U.S. Department of Justice, Hate Crime: The Violence of Intolerance, http://www. usdoj. gov/crs/pubs/htecrm.htm, diakses pada 1 Mei 2017, 22:04 WIB 